\title{
ФЕРМЕНТАТИВНОЕ БИОТЕСТИРОВАНИЕ ПОЧВ: СРАВНЕНИЕ ЧУВСТВИТЕЛЬНОСТИ К ТОКСИКАНТАМ МОНО-, БИ- И ТРИФЕРМЕНТНОЙ СИСТЕМ
}

\author{
(С) О. С. Сутормин, ${ }^{1,}{ }^{*}$ Е. М. Колосова, ${ }^{1}$ Е. В. Немцева, ${ }^{1,2}$ О. В. Искорнева, ${ }^{1}$ \\ А. Е. Лисица, ${ }^{1}$ В. С. Матвиенко, ${ }^{1}$ E. Н. Есимбекова, ${ }^{2,1}$ В. А. Кратасюк ${ }^{1,2}$ \\ ${ }^{1}$ Сибирский федеральный университет, Красноярск, 660041, и \\ ${ }^{2}$ Институт биофизики СО РАН, Красноярск, 660036; \\ * электронный адрес: OSutormin@sfu-kras.ru
}

\begin{abstract}
В работе исследовали возможности использования ферментных систем разной сложности в качестве биотестов для оценки степени загрязнения почв. Для этого определяли чувствительность моно-, би- и триферментной систем к пестицидам и ионам меди в воде и водных экстрактах из почв, различающихся гранулометрическим составом и содержанием гумуса. Системы включали в себя NAD(P)H:FMN-оксидоредуктазу и люциферазу светящихся бактерий, а также лактатдегидрогеназу. Для каждого тестируемого образца получали токсикологический параметр $\mathrm{EC}_{20}$, отражающий предел чувствительности тест-системы к загрязнителю. Установлено, что повышение сложности системы (от моно- до триферментной) увеличивает чувствительность биотеста, в некоторых случаях на несколько порядков. Полученные результаты говорят о возможности увеличения чувствительности ферментативных биотестов к токсикантам в почве за счет удлинения цепи сопряжения ферментов. Влияние экстрактов незагрязненных почв разных типов на ферментные системы также различается, что создает возможность конструирования специализированных ферментативных биотестов.
\end{abstract}

Ключевы е слова: биолюминесцентный анализ, почва, ферментативные биотесты, экологический мониторинг, бактериальная люцифераза, NAD(P)H:FMN-оксидоредуктаза, лактатдегидрогеназа, сопряженные ферментативные реакции

Пр ин я ты е с окра ще н и я: FMN — флавинмононуклеотид, L — люцифераза, LDH — лактатдегидрогеназа, R — NAD(P)H:FMN-оксидоредуктаза.

В настоящее время остро стоит проблема загрязнения окружающей среды и особенно почв, используемых в сельском хозяйстве. Деградация почв происходит вследствие их эрозии и дефляции, дегумификации, загрязнения техногенными радионуклидами, тяжелыми металлами, остатками пестицидов, удобрений и иными веществами, в разной степени опасными для здоровья человека и оптимального функционирования почвы. В утвержденной правительством РФ концепции ФЦП «Национальная система химической и биологической безопасности РФ (2009-2013 гг.)» качество почвы ряда регионов России характеризуется как критическое.

Для целей мониторинга экологической безопасности служат новые методы контроля токсичности почв, а также других компонентов природных и сельскохозяйственных экосистем (Добровольский, 2003; Колесников и др., 2006). Одним из важных современных приемов исследования в области экотоксикологии является биотестирование. Методы биотестирования используются с целью установления степени токсического действия химических, физических и биологически неблагоприятных факторов среды, потенциально опасных для живых компонентов экосисте- мы (MP 11-1/134-09, 2000). В последние годы активное развитие получило использование в качестве тест-объектов вместо живых организмов - ферментных систем различной сложности (Терехова, 2011; Kratasyuk, Esimbekova, 2015).

Цель настоящей работы - сравнить чувствительности моно-, би- и триферментной систем к пестицидам и ионам металлов для оценки возможности их использования в качестве биотестов для экологического мониторинга почв.

\section{Материал и методика}

Характеристика исследуемых почв и т о к с и к а н т в. Объектом исследования являлись 5 эталонных образцов почв (песок, легкий суглинок, средний суглинок, тяжелый суглинок и чернозем), отобранных в соответствии с ГОСТ 17.4.4.02-84 (2008). Экстракты из почв были приготовлены с использованием дистиллированной воды по следующей технологии: навеску почвы 5 г разводили 5-кратным объемом дистиллированной 
Параметр $\mathrm{EC}_{20}$ (мг/кг) для исследованных загрязнителей при использовании ферментных тест-систем R, R+L и R+L+LDH

\begin{tabular}{|c|c|c|c|c|c|c|c|c|c|}
\hline \multirow{2}{*}{ Образец } & \multicolumn{3}{|c|}{ Малатион } & \multicolumn{3}{|c|}{ Диазинон } & \multicolumn{3}{|c|}{ Хлорид меди (II) } \\
\hline & $\mathrm{R}$ & $\mathrm{R}+\mathrm{L}$ & $\mathrm{R}+\mathrm{L}+\mathrm{LDH}$ & $\mathrm{R}$ & $\mathrm{R}+\mathrm{L}$ & $\mathrm{R}+\mathrm{L}+\mathrm{LDH}$ & $\mathrm{R}$ & $\mathrm{R}+\mathrm{L}$ & $\mathrm{R}+\mathrm{L}+\mathrm{LDH}$ \\
\hline дН ${ }_{2} \mathrm{O}$ & 4400 & 39 & 2 & 350 & 1.3 & 0.35 & 0.4 & 0.06 & 0.004 \\
\hline Песок & - & 30 & 1 & 1500 & 1.15 & 0.15 & 169.8 & 0.21 & 0.004 \\
\hline Легкий суглинок & - & 600 & 20 & 300 & 9 & 3 & 6.35 & 0.12 & 0.004 \\
\hline Средний суглинок & - & 130 & 20 & 1800 & 2.4 & 0.5 & 17 & 0.03 & 0.16 \\
\hline Тяжелый суглинок & - & 18.5 & 8 & 300 & 16.5 & 0.15 & 21.25 & 0.55 & 0.04 \\
\hline Чернозем & - & 39 & 1 & 3000 & 1.7 & 0.3 & 255 & 0.7 & 0.0045 \\
\hline ПДК & \multicolumn{3}{|c|}{$1.0^{\mathrm{a}}$} & \multicolumn{3}{|c|}{$0.1^{\mathrm{a}}$} & \multicolumn{3}{|c|}{$3.0^{6}$} \\
\hline
\end{tabular}

Пр и мечан и е. ПДК в почве согласно гигиеническим нормативам: аГН 1.2.3111-13, 2014; бГН 2.1.7.2041-06, 2006.

воды. Данную смесь выдерживали 30 мин при непрерывном перемешивании при комнатной температуре, затем фильтровали. В качестве загрязняющих веществ выбраны пестициды малатион и диазинон, а также хлорид меди (II).

Анализ влияния образцов почв на активность ферментных систем. Активность

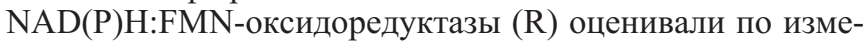
нению оптической плотности раствора при 340 нм с использованием спектрофотометра Cary 5000 (Agilent Technologies, США). Реакционная смесь: 660 мкл $0.05 \mathrm{M}$ калий-натрий-фосфатного буфера, $\mathrm{pH} 7.25,40$ мкл $\mathrm{R}$ (0.15 ед. акт./мл), 30 мкл 0.5 мМ FMN, 150 мкл 4 мМ $\mathrm{NADH}$ и 120 мкл дистиллированной воды (контроль) или тестируемого экстракта из почвы. Диапазон концентраций токсических веществ: 0.085-0.595 мг/л хлорида меди (II), $1.04-10.38$ мг/л малатиона и $0.35-0.85$ г/л диазинона.

Активность биферментной системы на основе $\mathrm{R}$ и бактериальной люциферазы (L) оценивали по интенсивности свечения с помощью люминометра Luminometer 20/20n (Promega, США). Реакционная смесь: 350 мкл 0.05 М калий-фосфатного буфера, $\mathrm{pH}$ 6.8, 5 мкл раствора ферментов R+L, 50 мкл $0.0025 \%$-ного тетрадеканаля, 100 мкл 0.4 мМ NADH, 10 мкл 0.5 мМ FMN и 50 мкл дистиллированной воды (контроль) или тестируемого экстракта из почвы. Диапазон концентраций токсических веществ: $0.015-0.15$ г/л хлорида меди (II), $0.0078-$ 0.78 мг/л малатиона и $0.23-53$ г/л диазинона.

Активность триферментной системы на основе R, L и лактатдегидрогеназы (LDH) оценивали по интенсивности свечения на люминометре Luminometer 20/20n (Promega, США). Реакционная смесь: 300 мкл 0.05 М калий-фосфатного буфера, pH 7.1, 5 мкл раствора LDH (0.5 мг/мл), 10 мкл раствора ферментов R и L, 10 мкл 15 мМ лактата, 100 мкл 0.5 мM NAD ${ }^{+}, 50$ мкл $0.0025 \%$-ного тетрадеканаля, 10 мкл 0.5 мM FMN и 50 мкл дистиллированной воды (контроль) или тестируемого экстракта почвы. Диапазон концентраций токсических веществ: 0.013-13 мг/л хлорида меди (II), 0.22-8.8 мг/л малатиона и 0.037-60 г/л диазинона.

Остаточную активность ферментной системы (Т) оценивали по формуле $\mathrm{T}=\mathrm{A}_{\mathrm{c}} / \mathrm{A}_{\mathrm{s}} \cdot 100 \%$, где $\mathrm{A}_{\mathrm{c}}$ и $\mathrm{A}_{\mathrm{s}}$ - coответственно активность ферментов в присутствии контрольного образца и раствора токсиканта или экстракта из почвы. Токсикологический параметр $\mathrm{EC}_{20}$ определяли как концентрацию токсиканта, при которой Т составляет 80 \%. Все эксперименты выполнены не менее 3 раз.

P еак т и в Ы. Лиофилизированные препараты L Photobacterium leiognathi (ЕC 1.14.14.3) и R Vibrio fischeri $\mathrm{EC}$ (1.5.1.29) (производство Лаборатории нанобиотехнологии и биолюминесценции Института биофизики СО РАН, Красноярск), LDH (Sigma-Aldrich, СШA), FMN и NADH (Serva, Германия), тетрадеканаль (Merck, Германия), $\mathrm{NAD}^{+}$(AppliChem, Германия), DL-молочная кислота (Sigma-Aldrich, США), малатион (Алсико-Агропром, Россия) и диазинон (МедиЛис, Россия), хлорид меди (II) двуводный марки «чда» (НПФ Невский химик, Россия).

\section{Результаты и обсуждение}

Влияние токсикантов на ферментные си стемы. На первом этапе исследовали влияние водных растворов токсикантов малатиона, диазинона и хлорида меди (II) на активность трех ферментных систем - R, $\mathrm{R}+\mathrm{L}$ и $\mathrm{R}+\mathrm{L}+\mathrm{LDH}$ (см. таблицу, образец д $\mathrm{H}_{2} \mathrm{O}$ ). По параметру $\mathrm{EC}_{20}$ установлено, что моноферментная система $\mathrm{R}$ малочувствительна к воздействию водных растворов малатиона $\left(\mathrm{EC}_{20} \gg\right.$ ПДК). Поэтому в экспериментах по оценке чувствительности системы R к токсикантам, содержащимся в экстрактах из почв, малатион был исключен. При работе с би- и триферментной системами анализировали влияние на активность ферментов каждого из трех токсикантов.

Влияние почв на ферментные системы. На следующем этапе исследовали влияние на ферментные системы пяти незагрязненных образцов почв с различным содержанием гумуса - песка, легкого суглинка, среднего суглинка, тяжелого суглинка и чернозема. Показано, что из пяти почвенных экстрактов на активность моноферментной системы R существенное ингибирующее влияние оказывает только экстракт из чернозема ( $\mathrm{T}=$ $=65 \%$ ). Активность биферментной системы R+L существенно снижалась в присутствии трех из исследуемых почвенных образцов - легкого суглинка ( го суглинка ( $\mathrm{T}=40 \%)$ и чернозема $(\mathrm{T}=20 \%)$. На активность триферментной системы $\mathrm{R}+\mathrm{L}+\mathrm{LDH}$ ингибирующее влияние оказали экстракты из песчаной почвы ( $\mathrm{T}=56 \%$ ), тяжелого суглинка $(\mathrm{T}=59 \%)$ и чернозема $(\mathrm{T}=36 \%)$. В дальнейшем для исключения влияния компонентов незагрязненной почвы на результаты ферментативного тес- 
тирования в качестве контроля использовали водный экстракт из почвы соответствующего типа.

Влияние токсикантов в экстрактах из почв на ферментные системы. Были проведены модельные эксперименты оценки чувствительности ферментных систем к воздействию токсических веществ при их внесении непосредственно в экстракты из почв. Варьируя концентрацию загрязнителя, определяли значения его токсикологического параметра $\mathrm{EC}_{20}$, показывающего предел чувствительности к нему системы (см. таблицу). Установлено, что смешивание токсикантов с экстрактом из почв в большинстве случаев приводит к снижению их ингибирующего воздействия на ферментные системы. Особенно это выражено для хлорида меди, чувствительность к которому падает на 3 и 1 порядок при тестировании этого токсиканта в экстракте из чернозема с помощью моно- и биферментной систем соответственно и на 1 порядок при его тестировании в экстракте из среднего суглинка с помощью системы $\mathrm{R}+\mathrm{L}+\mathrm{LDH}$.

Кроме того, сравнительный анализ активности ферментных систем в присутствии загрязненных и незагрязненных экстрактов почв показал, что активность R в присутствии экстрактов почв, загрязненных хлоридом меди, не отличается от активности фермента в присутствии экстрактов незагрязненных почв. Исходя из полученных результатов можно сделать вывод о том, что моноферментная система не позволяет фиксировать загрязнение почв хлоридом меди на уровне, близком к ПДК для данного вещества.

Полученные в работе результаты указывают на широкие возможности для управления чувствительностью ферментативных биотестов к токсикантам в почве за счет удлинения цепи сопряжения ферментов или подбора системы, подверженной наименьшему влиянию естественных компонентов почвы. Действительно, повышение сложности системы (от моно- до триферментной) в несколько раз увеличивает чувствительность ферментативного биотеста. Однако, с другой стороны, исследование выявило трудности проведения ферментативного биотестирования почв, связанные с активным влиянием экстрактов из почв как на активность ферментных систем, так и на их взаимодействие с токсикантами. Полученные результаты о различном влиянии незагрязненных экстрактов из почв на три ферментные системы открывают возможности для конструирования специализированных ферментативных биотестов для целей мониторинга эко- логической безопасности почв различного компонентного состава и загрязненности.

Работа выполнена при поддержке Российского научного фонда (проект 16-14-10115).

\section{Список литературы}

ГН 1.2.3111-13. 2014. Гигиенические нормативы содержания пестицидов в объектах окружающей среды (перечень). М.: Федеральный центр гигиены и эпидемиол. Роспотребнадзора. 131 c. (GN 1.2.3111-13. 2014. Hygienic norms of pesticide contents in environmental objects (list). Moscow: Federal Hygienic and Epidemiol. Center of Rospotrebnadzor. 131 p.)

ГН 2.1.7.2041-06. 2006. Предельно допустимые концентрации (ПДК) химических веществ в почве. М.: Федеральный центр гигиены и эпидемиол. Роспотребнадзора. 15 с. (GN 2.1.7.2041-06. 2006. Maximum permissible concentration (MPC) of chemical substances in soil. Moscow: Federal Hygienic and Epidemiol. Center of Rospotrebnadzor. 15 p.)

ГОСТ 17.4.4.02-84. 2008. Охрана природы. Почвы. Методы отбора и подготовки проб для химического, бактериологического, гельминтологического анализа. М.: Стандартинформ. 7 c. (GOST 17.4.4.02-84. 2008. Nature protection. Soils. Methods for sampling and preparation of soil for chemical, bacteriological, helmintological analisis. Moscow: Standartinform. 7 p.)

Добровольский Г. В. 2003. Структурно-функциональная роль почв и почвенной биоты в биосфере. М.: Наука. 364 с. (Dobrovolsky G. V. 2003. Structural and functional role of soils and soil biota in the biosphere. Moscow: Nauka. 364 p.)

Колесников С. И., Казеев К. Ш., Вальков В. Ф. 2006. Экологическое состояние и функции почв в условиях химического загрязнения. Ростов н/Д: Ростиздат. 385 с. (Kolesnikov S. I., Kazeev K. Sh., Valkov V. F. 2006. An ecological condition and functions of soils in the conditions of chemical pollution. Rostov on/D: Rostizdat. 385 p.)

MP 11-1/134-09. 2000. Определение общей токсичности почв по интенсивности биолюминесценции бактерий. М.: Федеральный центр Госсанэпиднадзора Минздрава России. 21 с. (MP 11-1/134-09. 2000. Determination of soil in intensity of bioluminescence general toxicity of bacteria. Moscow: Federal Hygienic and Epidemiological Center of Rospotrebnadzor. 21 p.)

Терехова B. A. 2011. Биотестирование почв: подходы и проблемы. Почвоведение. 2 : 190-198. (Terekhova V. A. 2011. Soil bioassay: problems and approaches. Eurasian Soil Science. 2 : 173-179.)

Kratasyuk V. A., Esimbekova E. N. 2015. Applications of luminous bacteria enzymes in toxicology. Combina. Chem. High Throughput Screening. $18: 952-959$.

\title{
ENZYMATIC BIOASSAY OF SOIL: SENSITIVITY COMPARISON OF MONO-, DOUBLE- AND TRIPLE-ENZYME SYSTEMS TO SOIL TOXICANTS
}

\author{
O. S. Sutormin, ${ }^{1,}$ * E. M. Kolosova,${ }^{1}$ E. V. Nemtseva,${ }^{1,2}$ O. V. Iskorneva,${ }^{1}$ A. E. Lisitsa,${ }^{1}$ \\ V. S. Matvienko, ${ }^{1}$ E. N. Esimbekova, ${ }^{2,1}$ V. A. Kratasyuk ${ }^{1,2}$ \\ ${ }^{1}$ Siberian Federal University, Krasnoyarsk, 660041, and \\ 2 Institute of Biophysics Siberian Branch of RAS, Krasnoyarsk, 660036; \\ * e-mail: OSutormin@sfu-kras.ru
}

In this paper, we have investigated the possibilities of application of enzymatic systems with increasing chain length as a bioassay to evaluate the soil contamination status. The sensitivity of monoenzyme reaction as well as double- and triple-enzyme chains based on NAD(P)H:FMN-oxidoreductase and luciferase of luminous bacteria and lactate dehydrogenase to pesticides and copper ions in water and water extracts from soils were es- 
timated. For this, the toxicological parameter $\mathrm{IC}_{20}$ reflecting the sensitivity limit of the enzyme system to the toxicant was used. It was revealed that elongation of the coupled enzyme chain (from mono- to triple-enzyme) increases the sensitivity of the bioassay, in some cases by several orders of magnitude. This pattern can be used as a tool to improve the properties of enzymic bioassays. The effect of extracts from uncontaminated soils of various types on enzymatic systems also differs, which makes possible to design the specialized enzymatic bioassays as well.

Key w ords: bioluminescent analysis, soil, enzymatic toxicity bioassays, ecological monitoring, bacterial luciferase, NADH:FMN-oxidoreductase, lactate dehydrogenase, coupled enzyme systems 